\title{
Reviews
}

\section{Genetic risk factors in Alzheimer's disease}

\author{
L Tilley, K Morgan, N Kalsheker
}

\begin{abstract}
Following a brief introduction and discussion of the pathological features of Alzheimer's disease, the main emphasis of this review article will be the genetic factors that have been implicated in this disease. These can be divided into two main categories. First, the three genes in which mutations are known to result in early onset autosomal dominant familial Alzheimer's disease will be discussed. These are well characterised but account for only a small proportion of Alzheimer's disease cases. Late onset, sporadic Alzheimer's disease is more common and evidence suggests that there is a genetic component to this type of disease. A number of genetic risk factors have been implicated that might increase the risk of developing sporadic disease. Many of these are controversial and studies have shown conflicting results, which are discussed in this section. Finally, a brief discussion of some of the mechanisms suggested to play a role in the pathogenesis of Alzheimer's disease is included. It is hoped that this will show why particular genes have been implicated in Alzheimer's disease and how they might be able to influence the development of the disease. (F Clin Pathol: Mol Pathol 1998;51:293-304)
\end{abstract}

Keywords: Alzheimer's disease; susceptibility genes; genetic risk factors

Alzheimer's disease is a progressive neurodegenerative disorder, first described by Alois Alzheimer. ${ }^{1}$ It is the leading cause of dementia in the elderly, accounting for around $50 \%$ of all dementias. The remaining $50 \%$ are caused by $\sim 70$ different disorders, but comprise mainly Lewy body dementia (20-30\%) and multiinfarct dementia (10-20\%), with the final 10\% being the atypical dementias such as Pick's disease, Huntington's disease, and CreutzfeldJacob's Disease (CJD). Estimates of the prevalence of Alzheimer's disease are variable, probably because of uncertainty in diagnosis, but increase from $0.3 \%$ in the $60-69$ year age group, to more than $10 \%$ in those over 80 years of age. ${ }^{2}$ It is estimated that there are more than 600000 people in the UK suffering from the disease.
Alzheimer's disease is characterised by progressive dementia beginning in middle to late life, with death occurring an average of 8-10 years after diagnosis. ${ }^{3}$ The clinical manifestations of the disease are extremely variable, with symptoms including memory loss, confusion, personality changes, impaired coordination, and speech problems.

Alzheimer's disease can be categorised according to its age of onset or mode of inheritance. The early onset disease is defined as having an age of onset before 65 years of age, and these cases are usually familial, being inherited in an autosomal dominant fashion. This type of Alzheimer's disease, known as familial Alzheimer's disease is rare, accounting for $\sim 10 \%$ of all Alzheimer's disease cases. Most Alzheimer's disease cases are of the late onset type, occurring in individuals over 65 years of age, and are sporadic, with no strong family history.

\section{Pathological features of Alzheimer's disease}

Pathologically, the Alzheimer's disease brain is characterised by two types of lesion: senile or neuritic plaques and neurofibrillary tangles. It has been shown that intellectual decline correlates with the densities of neurofibrillary tangles and senile plaques in the diseased brain. ${ }^{4}$ It is believed that the formation of these lesions is likely to result in the destruction of cell bodies, dendrites, and synapses, thus leading to severe impairment of neurotransmission and resulting in a decline in cognitive abilities.

\section{SENILE PLAQUES}

Senile plaques consist of a spherical extracellular core of proteinaceous fibrillar deposits, or amyloid, surrounded by degenerating nerve cell processes (fig 1). They are found particularly in the hippocampus, neocortex, and amygdala, and in the walls of cerebral and meningeal blood vessels. The predominant protein in the senile plaque core is a $4 \mathrm{kDa}$ peptide, ${ }^{5}$ known as $A \beta, \beta$-amyloid, $A 4$, or $\beta / A 4$. $\mathrm{A} \beta$ contains between 39 and 43 amino acids, differing at the C-terminus, with the 42 amino acid form being the most predominant form in amyloid deposits. ${ }^{6} \mathrm{~A} \beta$ is derived from a larger precursor protein known as the amyloid precursor protein $(\beta \mathrm{APP})$ via proteolytic cleavage. $^{78}$

In addition to $\mathrm{A} \beta$, a number of other senile plaque components have been identified. The 


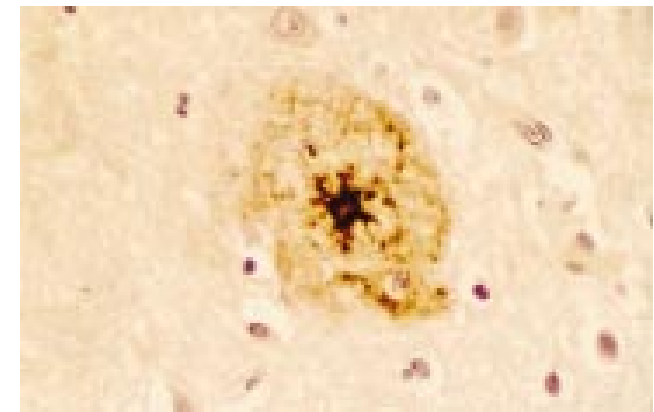

Figure 1 Typical Alzheimer's disease senile plaque immunostained for $A \beta$. The heavily stained dense core, composed of aggregated amyloid fibrils is seen clearly.

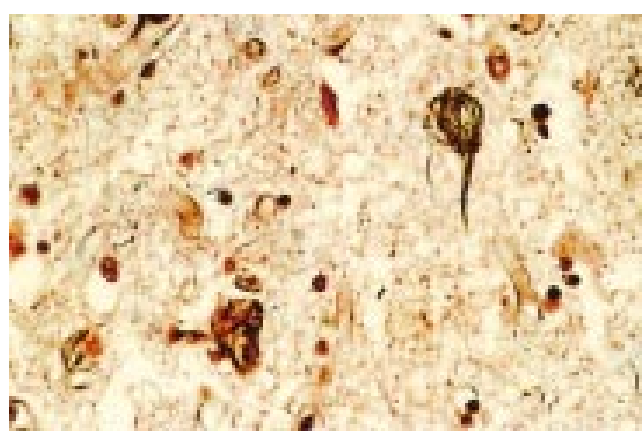

Figure 2 Alzheimer's disease brain tissue showing neurofibrillary tangles stained by Garvey's method. The darkly stained areas that are clearly visible are the hyperphosphorylated tau backbones of the neurofibrillary tangles.

serineproteinaseinhibitor(serpin) $\alpha_{1}$ antichymotrypsin has been shown to bind with high affinity to $A \beta$ and is found in the core of senile plaques. ${ }^{9-11}$ Immunohistochemical studies have also detected apolipoprotein E (apoE), associated with both senile plaque amyloid and neurofibrillary tangles in the Alzheimer's disease brain. ${ }^{12}$

NEUROFIBRILLARY TANGLES

Neurofibrillary tangles are abnormal proteinaceous deposits, which form as intraneuronal inclusions but become externalised as their neuronal source degenerates (fig 2). They occur in cell bodies and apical dendrites of degenerating neurons surrounding the core of senile plaques. Neurofibrillary tangles are a common feature of dystrophic neurons and are not specific to Alzheimer's disease, also being characteristic of other neurodegenerative diseases, such as Parkinson's disease. Their main structural component is an abnormal fibre known as a paired helical filament. It is likely that the sole component of these paired helical filaments is a hyperphosphorylated form of the microtubule associated protein tau. ${ }^{13}$

Table 1 Genes involved in early onset, autosomal dominant familial Alzheimer's disease (FAD)

\begin{tabular}{llllll}
\hline $\begin{array}{l}\text { Chromosomal } \\
\text { location }\end{array}$ & Gene & $\begin{array}{l}\text { Estimated } \\
\text { FAD cases }\end{array}$ & $\begin{array}{l}\text { Age of } \\
\text { onset } \\
\text { (years) }\end{array}$ & $\begin{array}{l}\text { No. of } \\
\text { mutations }\end{array}$ & Possible mechanism \\
\hline $21 \mathrm{q} 21.1$ & APP & Up to 5\% & $43-62$ & 6 & $\begin{array}{l}\text { Altered APP processing } \\
\text { Increase in A } \beta / \mathrm{A} \beta_{1-42}\end{array}$ \\
$14 \mathrm{q} 24$ & PS-1 & Up to 80\% & $29-62$ & $35+$ & $\begin{array}{l}\text { Increase in A } \beta_{1-42} \\
\text { Altered PS-1 metabolism } \\
\text { Increase in A } \beta_{1-42}\end{array}$ \\
$1 \mathrm{q} 31-42$ & PS-2 & $\sim 20 \%$ & $40-88$ & 2 &
\end{tabular}

APP, amyloid precursor protein; PS-1, presenilin 1.
Hyperphosphorylated tau in neurofibrillary tangles is also known to be ubiquitinated, ${ }^{14}$ suggesting a role for the ubiquitin dependant proteolysis pathway in Alzheimer's disease.

\section{Genetics of Alzheimer's disease}

In a number of families Alzheimer's disease is inherited as an autosomal dominant disorder, although in most cases inheritance appears to be multifactorial. Monozygotic twin studies indicate a variable concordance of between $18 \%{ }^{15}$ and $41 \%,{ }^{16}$ showing that Alzheimer's disease cannot be explained completely by a single autosomal dominant gene. A relative risk of 3.5 has been demonstrated for those with at least one first degree relative suffering from dementia. ${ }^{17}$

\section{Autosomal dominant gene mutations}

Three genes have been identified to date in which mutations result in early onset familial Alzheimer's disease, inherited in an autosomal dominant fashion. These are the amyloid precursor protein (APP), presenilin 1 (PS-1), and PS-2 genes (table 1).

THE APP GENE

The APP gene maps to chromosome $21 \mathrm{q} 21.1,{ }^{8}$ and mutations in this gene are estimated to account for up to 5\% of familial Alzheimer's disease cases. A number of mutations have been identified, at codons $717,{ }^{18-20} 670 / 671,{ }^{21}$ $692,{ }^{22}$ and $693 .{ }^{23}$ Mutations in the APP gene lead to early onset disease with age of onset typically between 43 and 62 years. ${ }^{24}$

Mutations in the APP gene might result in altered metabolism of APP, leading to increased production of the $A \beta$ protein, or an increased production of the 42 amino acid form of $\mathrm{A} \beta\left(\mathrm{A} \beta_{1-42}\right)$. This is the predominant form in senile plaques, and is thought to be more amyloidogenic, forming amyloid fibrils more rapidly than the shorter forms of $A \beta{ }^{6}$

THE PS-1 GENE

A second familial Alzheimer's disease locus was identified by genetic linkage analysis at chromosome $14 \mathrm{q} 24 .^{25-27}$ The gene responsible was subsequently identified as S182 or PS-1, and mutations in this gene are thought to cause up to $80 \%$ of familial Alzheimer's disease cases, with onset as early as 29 years of age, ${ }^{28}$ ranging to 62 years of age. ${ }^{24}$ To date, more than 35 missense mutations, and one in frame deletion ${ }^{29}$ have been identified in the PS-1 gene in affected families.

The fact that most PS mutations are missense ones suggests that Alzheimer's disease pathology is a result, not of the absence of the PS-1 gene product, but of its abnormal functioning as a result of the mutation. The function of the PS-1 protein is unknown, but it is known to be a transmembrane protein and, therefore, might function as a cell surface receptor, ion channel, or membrane structural protein. ${ }^{30}$ The PS- 1 protein is homologous to SEL-12 in Caenorhabditis elegans, ${ }^{31}$ a protein known to be involved in cell signalling during development. The PS-1 gene product is known to be essential during development because 
Table 2 Susceptibility genes in which polymorphisms have been reported to influence Alzheimer's disease risk

\begin{tabular}{|c|c|c|c|c|c|}
\hline Gene & $\begin{array}{l}\text { Chromosomal } \\
\text { location }\end{array}$ & Risk factor & Onset & Familial/sporadic & Other information \\
\hline APOE & $19 \mathrm{q} 13.2$ & $\varepsilon 4$ allele & $\begin{array}{l}\text { LOAD and } \\
\text { EOAD }\end{array}$ & $\begin{array}{l}\text { Familial and } \\
\text { sporadic }\end{array}$ & \\
\hline APOE & $19 \mathrm{q} 13.2$ & $-491 \mathrm{~A}$ allele & LOAD & Sporadic & APOE $\varepsilon 4$ independent \\
\hline APOE & $19 \mathrm{q} 13.2$ & TATA box $\mathrm{T}$ allele & LOAD & Sporadic & Modifies APOE $\varepsilon 4$ effect \\
\hline VLDL-R & 9 & $\begin{array}{l}\text { Trinucleotide five } \\
\text { repeat allele }\end{array}$ & LOAD & Sporadic & In APOE $\varepsilon 4$ carriers only \\
\hline LRP & 12 & $\begin{array}{l}\text { Exon } 3 \mathrm{CC} \\
\text { genotype }\end{array}$ & LOAD & $\begin{array}{l}\text { Familial and } \\
\text { sporadic }\end{array}$ & \\
\hline LRP & 12 & $\begin{array}{l}\text { TTTC repeat } \\
\text { polymorphism }\end{array}$ & LOAD & Sporadic & \\
\hline A2M & $12 p$ & A2M-2 allele & LOAD & Familial & No interaction with $\mathrm{APOE}$ \\
\hline PS-1 & $14 \mathrm{q} 24$ & Intron 8 , allele 1 & LOAD & Sporadic & \\
\hline $\mathrm{BChE}$ & $3 q 26.1-2$ & $\mathrm{~K}$ allele & $\begin{array}{l}\text { LOAD (over } 75 \\
\text { years) }\end{array}$ & Sporadic & In APOE $\varepsilon 4$ carriers only \\
\hline ACT & $14 \mathrm{q} 32.1$ & $\begin{array}{l}\text { Signal sequence A } \\
\text { allele }\end{array}$ & LOAD & $\begin{array}{l}\text { Familial and } \\
\text { sporadic }\end{array}$ & In association with $\mathrm{APOE} \varepsilon 4$ \\
\hline $\mathrm{ACT}$ & $14 \mathrm{q} 32.1$ & $\begin{array}{l}\text { Microsatellite A10 } \\
\text { allele }\end{array}$ & LOAD & Sporadic & In association with APOE $\varepsilon 4$ \\
\hline
\end{tabular}

EOAD, early onset Alzheimer's disease; LOAD, late onset Alzheimer's disease; ACT, $\alpha_{1}$ antichymotrypsin; A2M, $\alpha_{2}$ macroglobulin; APOE, apolipoprotein E; BChE, butyrylcholinesterase; LRP, low density lipoprotein receptor related protein; PS-1, presenilin 1; VLDL-R, very low density lipoprotein receptor.

PS-1 gene knockout mice exhibit skeletal deformations, impaired neurogenesis, and neuronal cell death, leading to death shortly after birth. 3233

THE PS-2 GENE

Although mutations in the PS-1 gene account for most cases of familial Alzheimer's disease, there are some affected families in which both APP and PS-1 mutations have been excluded. A third locus was identified at chromosome $1 \mathrm{q} 31-42,{ }^{34}$ and the mutated gene was identified subsequently as STM-2 or PS- $2 .{ }^{35}$ Only two mutations have been identified in the PS-2 gene to date, leading to Alzheimer's disease with an onset between 40 and 88 years of age, typically later than that seen in PS-1 linked cases. ${ }^{24}$

The PS-1 and PS-2 proteins were found to be highly homologous, sharing $67 \%$ identity. The PS-2 protein is proposed to have a similar function to the PS-1 protein, although they are unable to compensate for each other. It has been demonstrated that mutations in both the PS- 1 and PS-2 gene cause over production of the amyloidogenic $\mathrm{A} \beta_{1-42}$ form in both transfected cells and transgenic mice. ${ }^{36-38}$ Presenilin mutations cause dominant gain of function, with mutant genes leading to an increase in $\mathrm{A} \beta_{1-42}$ production, even in the presence of wildtype alleles. It has also been reported that PS-1 mutations lead to altered protein metabolism, resulting in accumulation of $\mathrm{N}$-terminal and C-terminal PS-1 protein fragments in brains of transgenic mice. ${ }^{39}$ However, it is not clear how this accumulation of fragments contributes to neurodegeneration.

\section{Susceptibility genes}

Only a small proportion $(\sim 10 \%)$ of Alzheimer's disease cases are caused by mutations inherited in an autosomal dominant fashion. Most cases are late onset and apparently sporadic, probably as a result of a combination of environmental and non-dominant genetic factors. A number of genetic risk factors have been implicated in Alzheimer's disease, which are not sufficient to cause the disease, but may greatly increase the risk above that of the general population; these are susceptibility genes (table 2).

APOLIPOPROTEIN E (APOE) GENE

The gene for apolipoprotein $\mathrm{E}$ (apoE) is located in a cluster of apolipoprotein genes at chromosome 19q13.2. This region was first implicated in late onset Alzheimer's disease by linkage studies. ${ }^{40-42}$ apoE is a $34 \mathrm{kDa}$ glycoprotein encoded by a polymorphic gene resulting in three common alleles, named $\varepsilon 2, \varepsilon 3$, and $\varepsilon 4$. The APOE $\varepsilon 4$ allele is a well established risk factor for late onset Alzheimer's disease, with a significantly higher frequency observed in Alzheimer's disease cases than in controls. ${ }^{43-45}$ This association has been confirmed for both familial and sporadic late onset Alzheimer's disease, ${ }^{44} 45$ and has also been reported in the early onset disease. ${ }^{46} 47$

The APOE $\varepsilon 4$ risk has been shown to be dose dependant, the risk increasing with the number of $\varepsilon 4$ alleles. One study has reported an odds ratio of 2.8 for individuals with one $\varepsilon 4$ allele, increasing to 8.1 for individuals homozygous for the $\varepsilon 4$ allele, compared with individuals with no $\varepsilon 4$ alleles. ${ }^{43}$ It has also been shown that each $\varepsilon 4$ allele lowers the age of onset by seven to nine years in late onset familial Alzheimer's disease. ${ }^{43} 4849$

A gender difference has been suggested for APOE associated risks ${ }^{50}{ }^{51}$ but other studies have failed to confirm this difference. ${ }^{52}{ }^{53}$ However, the former studies ${ }^{50}$ only considered data from families, so the proposed sex specific risk might only apply in familial Alzheimer's disease.

In contrast to the increased risk conferred by possession of the $\varepsilon 4$ allele, a protective effect has been proposed for the $\varepsilon 2$ allele. It has been observed in several studies that individuals possessing the $\varepsilon 2$ allele have a lower incidence of Alzheimer's disease. ${ }^{5354}$ However, other studies have failed to find this association,,$^{55}$ and some studies have conversely suggested that the $\varepsilon 2$ allele acts as a risk factor in the early onset disease. ${ }^{5657}$ 
Recently, two polymorphisms within the APOE gene regulatory regions have been reported to play a role in Alzheimer's disease. A $\mathrm{G} / \mathrm{T}$ biallelic polymorphism in the APOE gene TATA box may modulate the influence of the APOE $\varepsilon 4$ allele on the risk of disease,${ }^{58}$ whereas an $\mathrm{A} / \mathrm{T}$ polymorphism at position -491 was associated with Alzheimer's disease risk independently of APOE $\varepsilon 4$ status. ${ }^{59}$ Homozygosity for $-491 \mathrm{~A}$ was found to confer an increased risk of disease, possibly by altering the level of apoE protein production. The A allele was associated with higher constitutive levels of APOE promoter activity, as a result of differences in affinity for nuclear proteins between the two alleles. However, a subsequent study has failed to reproduce the association between the -491 regulatory region polymorphism and Alzheimer's disease, ${ }^{60}$ although results suggest that the frequency of the -491 $\mathrm{A} / \mathrm{T}$ polymorphism may vary considerably between different ethnic groups.

Although the APOE $\varepsilon 4$ allele is a well documented risk factor for Alzheimer's disease, it is neither necessary nor sufficient for development of the disease. This implicates the involvement of other factors, either genetic or environmental, acting either independently or in association with the APOE $\& 4$ allele. One study has reported that the presence of herpes simplex virus type I (HSV-I) DNA in the brain, together with possession of the APOE $\varepsilon 4$ allele, is a strong risk factor for Alzheimer's disease. ${ }^{61}$ In addition, various genetic factors have been reported to modify the risk associated with APOE $\varepsilon 4$ (see below) but none, as yet, have been as convincing, or reproducible in different study groups, as the APOE effect.

VERY LOW DENSITY LIPOPROTEIN RECEPTOR (VLDL-R) GENE

Receptors for apoE containing lipoproteins such as the VLDL-R have been proposed to act as risk factors for Alzheimer's disease, by influencing the metabolism of $\mathrm{apoE}$ in the brain. The VLDL-R gene is located on chromosome $9,^{62}$ and contains a polymorphic trinucleotide tandem repeat $(\mathrm{CGG})_{\mathrm{n}}$ in the $5^{\prime}$ untranslated region, ${ }^{62}{ }^{63}$ with alleles ranging from four to nine repeats. It has been observed in a Japanese population that homozygosity for the five repeat allele, in association with possession of the APOE $\varepsilon 4$ allele, confers an increased risk of developing Alzheimer's disease above that associated with possession of the APOE $\varepsilon 4$ allele alone ${ }^{64}$ However, subsequent studies in white populations ${ }^{65-69}$ have failed to find any association, although there are marked differences in allele frequencies between the Japanese and white populations. ${ }^{70}$ Thus, it is possible that the VLDL-R five repeat allele acts as an Alzheimer's disease risk factor in Japanese populations only, although a further study in a Japanese population has also failed to find any association. ${ }^{71}$ It seems unlikely that the VLDL-R polymorphism plays a role in the late onset disease in white populations, but further studies are required to confirm its importance in Japanese populations.
In addition to VLDL-R, other lipoprotein receptors have also been investigated as candidate risk factors for late onset Alzheimer's disease. Studies of the low density lipoprotein receptor (LDL-R) gene have shown no association with Alzheimer's disease. ${ }^{68}$ The LDL-R related protein (LRP) gene, located on chromosome 12 , has also been suggested as a candidate risk factor in the late onset disease. The LRP protein is the main apoE receptor in the brain, and is also responsible for endocytosis of secreted APP, suggesting a possible role in the pathogenesis of Alzheimer's disease. Studies involving a TTTC repeat polymorphism in the 5 ' end of the LRP gene have shown conflicting results. ${ }^{68} 72-74$ Studies using an alternative marker, a silent $\mathrm{C} / \mathrm{T}$ polymorphism in exon 3 of the LRP gene, suggest that the CC genotype is over represented in patients with Alzheimer's disease compared with controls, in both familial $^{75}$ and sporadic ${ }^{76}$ late onset disease. Linkage data implicating a locus on chromosome 12 in late onset Alzheimer's disease ${ }^{77}$ also suggest that the LRP locus might be important.

$\alpha_{2}$ MACROGLOBULIN GENE (A2M)

$\alpha_{2}$ Macroglobulin is a serum pan-protease inhibitor that has been implicated in Alzheimer's disease because of its presence in senile plaques ${ }^{78}$ and its ability to bind $A \beta,{ }^{79} 80$ attenuating both fibril aggregation and neurotoxicity. ${ }^{80}$ Along with apoE and $\beta \mathrm{APP},{ }^{75}{ }^{82} \alpha_{2}$ macroglobulin is a major ligand for the LRP receptor, which has also been implicated in Alzheimer's disease.

A splice acceptor deletion in exon 18 of the $\alpha_{2}$ macroglobulin gene, known as $\mathrm{A} 2 \mathrm{M}-2,{ }^{83}$ has been reported recently to be associated with an increased risk of Alzheimer's disease. ${ }^{84}$ Using a sibling study approach, the frequency of the A2M-2 allele was found to be higher in probands than in unaffected individuals. The odds ratio associated with possession of at least one copy of the A2M-2 allele was 3.6, similar in magnitude to that associated with homozygosity for the APOE $\varepsilon 4$ allele in this study.

These findings are interesting in the light of reports implicating a locus on chromosome 12 associated with Alzheimer's disease. ${ }^{77}$ A2M maps to chromosome $12 \mathrm{p}$, within $30 \mathrm{cM}$ of the implicated chromosome 12 markers. ${ }^{84}$ Thus, further study of the A2M gene is justified, and as the odds ratio associated with the A2M-2 allele is similar in magnitude, or larger, than that associated with the APOE $\varepsilon 4$ allele, this gene could prove to be an important risk factor in Alzheimer's disease.

THE PS-1 GENE

Although the PS-1 gene is generally thought to be involved only in early onset familial Alzheimer's disease, allele sharing between affected family members with late onset disease has been observed, ${ }^{85}$ suggesting a further role for PS-1 in late onset Alzheimer's disease. It has been reported that a biallelic polymorphism within intron 8 of the PS- 1 gene acts as a risk factor for late onset disease, with homozygosity for allele 1 being associated with an approximate doubling of risk when 
compared with individuals with either one or no copies of allele $1 .^{86}$ This association has been confirmed in two subsequent studies, ${ }^{87} 88$ but others have failed to find an association. ${ }^{89-92}$

BUTYRYLCHOLINESTERASE (BChE) GENE

The BChE gene is located at chromosome 3q26.1-26.2. BChE is expressed in most human tissues but its function is unknown. $\mathrm{BChE}$ activity in the brain increases in an age dependant fashion after 60 years of age, and is raised in Alzheimer's disease. ${ }^{93} \mathrm{BChE}$ has been detected histochemically in both senile plaques and neurofibrillary tangles in brains affected by Alzheimer's disease..$^{94-96}$

A variant of the $\mathrm{BChE}$ gene known as the $\mathrm{BChE}-\mathrm{K}$ variant has a point mutation at nucleotide 1615 (GCA $\rightarrow$ ACA), resulting in a change of alanine 539 to threonine. This mutation reduces the catalytic activity of BChE by one third. ${ }^{97}$ Recently, it has been reported that the $\mathrm{BChE}-\mathrm{K}$ variant is more common in patients with late onset Alzheimer's disease than in controls, other dementias, and patients with early onset Alzheimer's disease. ${ }^{98}$ The BChE-K variant was associated with a twofold increased risk of developing Alzheimer's disease, with the strongest effect observed in the over 75 age group. When APOE $\varepsilon 4$ carrier status was also taken into account, possession of both APOE $\varepsilon 4$ and BChE-K alleles was found to be associated with a 36 times greater risk when compared with individuals with neither allele. However, two subsequent studies have failed to confirm this finding. ${ }^{99} 100$

$\alpha_{1}$ ANTICHYMOTRYPSIN (ACT) GENE

The presence of ACT in the cores of senile plaques, the high expression of ACT mRNA in brains affected by Alzheimer's disease, ${ }^{9-11}$ and the ability of ACT to promote aggregation of $\mathrm{A} \beta$ fibrils, ${ }^{101}$ suggest an important role for ACT in the pathogenesis of Alzheimer's disease. The ACT gene maps to chromosome 14q32.1, and contains a common biallelic polymorphism in the signal sequence, resulting in either an alanine (A) or a threonine (T) at position -17 of the ACT protein. It has been reported that the A allele of this signal sequence polymorphism is associated with an increased risk of Alzheimer's disease in APOE $\varepsilon 4$ carriers only. ${ }^{102-104}$ It has also been reported that the ACT/AA genotype is associated with an increased risk of Parkinson's disease, ${ }^{105} \mathrm{a}$ disease with similar pathology to Alzheimer's disease. However, many studies in Alzheimer's disease populations have failed to confirm the role of the ACT signal sequence A allele as a late onset disease risk factor, ${ }^{93}{ }^{106-113}$ although Talbot and colleagues ${ }^{109}$ did observe that the combination of the APOE $\varepsilon 4$ allele and the ACT/AA genotype may result in a lower age of onset.

The A10 allele of a polymorphic dinucleotide TC/TA repeat located in the 5 ' flanking region of the ACT gene has also been reported to act as a risk factor for late onset Alzheimer's disease, in association with APOE $\varepsilon 4 .{ }^{113}$ Strong linkage disequilibrium was observed between the A10 microsatellite allele and the ACT sig- nal sequence $\mathrm{T}$ allele in both the control and Alzheimer's disease groups. These findings are therefore contradictory to the reports of an association between the ACT A allele and Alzheimer's disease.

\section{MITOCHONDRIAL DNA MUTATIONS}

Some evidence suggests that Alzheimer's disease can show a pattern of maternal inheritance, whereby the offspring of mothers with Alzheimer's disease have an increased risk of Alzheimer's disease compared with offspring of affected fathers. ${ }^{114}$ Because mitochondrial DNA is maternally inherited, this implicates the involvement of mitochondrial DNA mutations in Alzheimer's disease. However, studies of various mitochondrial DNA mutations that have been reported to influence the risk of Alzheimer's disease have yielded inconsistent results.

Mutations in the cytochrome $\mathrm{C}$ oxidase genes COI and COII ${ }^{115}$ and in the ND2 gene, encoding subunit 2 of respiratory chain complex $\mathrm{I}^{116}$ have been reported to cause an increased risk of Alzheimer's disease. However, several subsequent studies have failed to confirm these findings. ${ }^{117-119}$ A variant of a mitochondrial tRNA gene has also been reported to be associated with the late onset disease, again with conflicting results. ${ }^{117}{ }^{119-122}$ It is possible that any observed mitochondrial DNA alterations in patients with Alzheimer's disease occur as a result of the neurodegenerative process, rather than being heritable risk factors.

OTHER LOCI?

A complete genomic screen in familial late onset Alzheimer's disease has identified four regions of interest in the genome, on chromosomes $4,6,12$, and 20 , with a region near the centromere of chromosome 12 showing the strongest linkage. ${ }^{77}$ In this study, the effect of the chromosome 12 locus appears to be greatest in families in which the APOE $\varepsilon 4$ allele has little influence on the risk of Alzheimer's disease. Although the LRP gene, a candidate Alzheimer's disease risk factor, is located on chromosome 12, the Pericak-Vance study ${ }^{77}$ shows no significant association with this gene in either familial or sporadic disease groups. One study has also reported a potential locus on the $\mathrm{X}$ chromosome. ${ }^{123}$

\section{THE VALUE OF ASSOCIATION STUDIES}

It can be seen from the previous section on risk factors in Alzheimer's disease that the results obtained from association studies have provided conflicting data in a number of instances. Of the more than 70000 genes believed to be expressed in the brain it would be remarkably fortuitous if the ones currently known (just over 2000) included all those associated with the disease state. It is far more likely that other genetic risk factors for Alzheimer's disease remain to be identified. However, the potential success of the association study approach is illustrated by the data obtained from APOE $\varepsilon 4$ studies, which are robust and readily reproduced by many workers in the field. 
A number of other factors could be contributing to the discrepancies noted in the literature. It is essential that the study groups used are closely matched for age, sex, and ethnic background because a number of alleles have been shown to vary with each of these parameters. There is also a problem with the accuracy of the diagnosis of Alzheimer's disease; although a clinical diagnosis of dementia is relatively straightforward, attributing a diagnosis of Alzheimer's disease is more problematical. A number of other pathologies (for example, Lewy body dementia, tangle only dementia, Pick's disease) present in a similar way and cannot be excluded easily on clinical grounds. Some would argue that all patients (both study and control groups) need to have their diagnoses confirmed histopathologically before inclusion in any study. It is quite possible that the genetics of these neuropathological diseases differ and inclusion of different phenotypes within a study group will obviously lead to a potential diminution of any association. Also, to increase the power of detection of any potential associations and resolve conflicting results between studies, study group sizes need to be increased substantially. Power calculations indicate that sample numbers should be in the thousands, rather than the hundreds, to detect potentially weak associations.

Another problem that needs to be addressed is how to accommodate the strong APOE $\varepsilon 4$ effect, which is apparent in all studies of late onset disease. Better mathematical models for complex multigenic disorders are required so that the APOE $\varepsilon 4$ effect can be removed and the effect of other loci established. This becomes even more important when the individual effect of a particular allele is small but in combination with other risk factors may become more potent. Synergy analysis ${ }^{124}$ attempts to address this issue and this type of approach might be useful in future association studies. Another approach would be to study only $\mathrm{APOE} \varepsilon 4$ negative patients and controls, thereby eliminating the APOE $\varepsilon 4$ effect completely.

The late onset nature of Alzheimer's disease causes obvious difficulties with study design, making pedigree analysis almost impossible. Sibling studies, which are usually very informative, would be of less value in Alzheimer's disease, because knowledge of parental genotypes is desirable to draw any conclusions regarding a particular locus. Although association studies are prone to a number of very real problems, it seems that they are the best approach that can be applied to Alzheimer's disease at this time, and can yield valuable information, as demonstrated by APOE studies.

\section{Pathogenesis of Alzheimer's disease} CHOLINERGIC HYPOTHESIS

It has been observed that there is a cholinergic deficit in Alzheimer's disease brains, with reduced concentrations of choline acetyltransferase and acetylcholinesterase. ${ }^{125-127}$ The extent of this deficiency seems to correlate with the density of lesions, with greatest reductions in choline acetyltransferase and acetylcholinesterase activities in areas of the brain with high numbers of senile plaques and neurofibrillary tangles. ${ }^{128}$ The cholinergic deficit also appears to correlate with the extent of intellectual decline in patients with Alzheimer's disease.

However, Alzheimer's disease cannot be regarded as primarily a disorder of the cholinergic system, because patients have been reported with the classic neuropathological features of Alzheimer's disease, but without a reduction in choline acetyltransferase activity. ${ }^{129}$ In addition, reduction in choline acetyltransferase activity of a similar magnitude to that seen typically in Alzheimer's disease has been reported in other neurodegenerative conditions, without associated severe cognitive decline. ${ }^{130}$ The cholinergic deficit probably only explains part of the observed cognitive decline in patients with Alzheimer's disease. Other neurotransmitter changes also occur, including reduction of noradrenaline and serotonin in the cerebral cortex.

AMYLOID CASCADE HYPOTHESIS

This hypothesis states that the deposition of $A \beta$ protein is the primary event in the pathogenesis of Alzheimer's disease, and that neurofibrillary tangles, neuronal death, and dementia occur subsequently as a result of this event. ${ }^{131}$ The cascade hypothesis assumes that $\mathrm{A} \beta$ and $\beta \mathrm{APP}$ cleavage products containing $A \beta$ are neurotoxic. Two successive events are required to cause Alzheimer's disease; first intact $\mathrm{A} \beta$ must be produced, and second this must facilitate or cause cell death and neurofibrillary tangle formation.

$\mathrm{A} \beta$ has been reported to have both neurotrophic ${ }^{132} 133$ and neurotoxic ${ }^{134} 135$ effects in vitro. The toxicity seems to depend on the fibrillar state of $\mathrm{A} \beta,{ }^{136}$ and can be attenuated by both apoE ${ }^{137}$ and ACT. ${ }^{138}$ Aggregated $A \beta$ may either kill neurons directly ${ }^{135}$ or increase the vulnerability of neurons to other insults such as excitotoxicity, hypoglycaemia, and peroxidative damage. ${ }^{139}$ It has also been suggested that $\mathrm{A} \beta$ disrupts calcium homeostasis, resulting in increased concentrations of intraneuronal calcium. It has been shown that tau phosphorylation is regulated by intracellular calcium concentrations, ${ }^{140}$ therefore suggesting a mechanism by which $\mathrm{A} \beta$ causes neurofibrillary tangle formation.

The amyloid cascade hypothesis is supported by the presence of familial Alzheimer's disease mutations in $\beta A P P$ that apparently alter $\beta A P P$ processing and favour amyloid plaque formation. The fact that individuals with Down's syndrome (trisomy 21) develop Alzheimer's disease-like pathology early in life also shows that overexpression of $\beta A P P$ can cause Alzheimer's disease pathology, supporting a central role for $A \beta$ deposition in Alzheimer's disease.

It has been suggested that the presenilin familial Alzheimer's disease mutations also cause disease by altering the processing of $\beta A P P$ in a similar way to mutations in the $\beta A P P$ gene itself. It has been demonstrated 


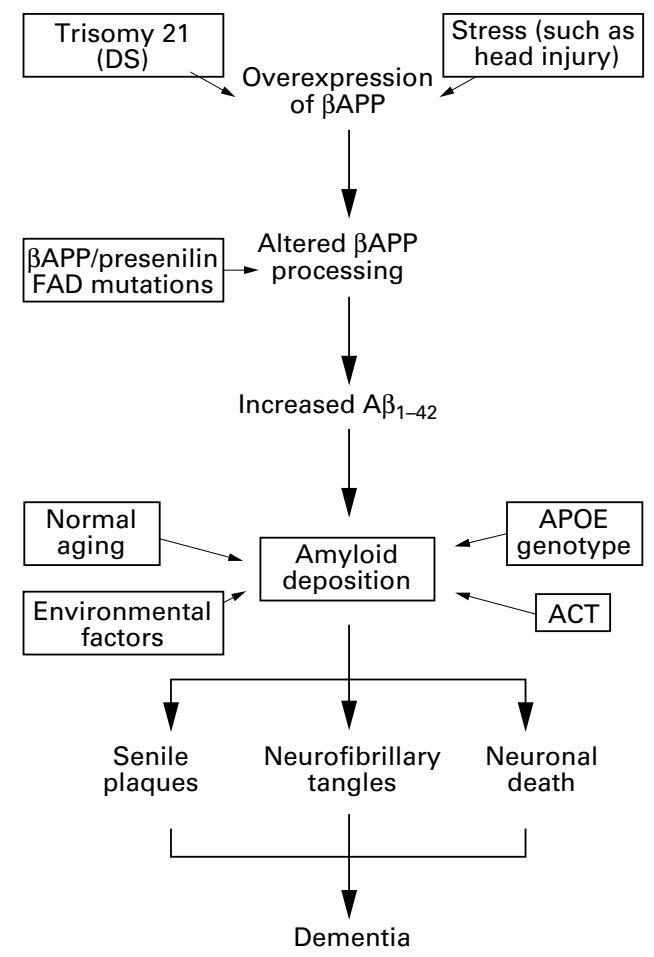

Figure 3 The amyloid cascade hypothesis: genetic and environmental factors act in combination to increase amyloid deposition, resulting in formation of senile plaques, neurofibrillary tangles and neuronal death. Ultimately, this leads to the symptoms of dementia. FAD, familial Alzheimer's disease.

that both PS-1 and PS-2 familial Alzheimer's disease mutations cause an increase in the concentration of $A \beta_{1-42}$, therefore leading to increased amyloid deposition. ${ }^{36-38}$ Other genetic and environmental factors might act on the cascade at this point by stimulating aggregation of $\mathrm{A} \beta$ - for example, both apoE and $\mathrm{ACT}^{101}$ can enhance aggregation of $\mathrm{A} \beta$ in vitro. The potential effects of both genetic and environmental factors on the amyloid cascade are depicted in fig 3.

HYPERPHOSPHORYLATION OF TAU AND

NEUROFIBRILLARY TANGLE FORMATION

The main argument against the amyloid cascade hypothesis is that neurofibrillary tangle formation has been shown to precede $A \beta$ deposition, ${ }^{141}$ and densities of neurofibrillary tangles, rather than senile plaques, correlate closely with the extent of intellectual decline in patients with Alzheimer's disease. The presence of neurofibrillary tangles in the absence of amyloid deposits (for example in Parkinson's disease) demonstrates that amyloid is not an absolute prerequisite for neurofibrillary tangle formation.

Neurofibrillary tangles are composed mainly of a hyperphosphorylated form of the tau protein. Tau is a microtubule associated protein present in both the central and peripheral nervous systems. In the brain it is found predominantly in the axons of nerve cells, and its normal function is to promote the assembly and stability of microtubules by binding to tubulin. Native tau is a phosphoprotein, and the affinity of tau for microtubules appears to be regulated by the level of phosphorylation. ${ }^{142}$ In brains of patients with Alzheimer's disease, tau becomes hyperphosphorylated and its ability to bind microtubules is greatly reduced, ${ }^{142}$ thus leading to destabilisation of the microtubule system. This could lead to diminished axoplasmic flow and, therefore, a reduced supply of substrates to the axons and dendrites, resulting in neuronal death. ${ }^{143}$ Hyperphosphorylated tau, being unable to bind microtubules, is therefore available to assemble into paired helical filaments.

APOE genotype has been reported to influence tau hyperphosphorylation, with the apoE $\varepsilon 3$ protein, but not $\varepsilon 4$, being capable of binding to tau and preventing hyperphosphorylation. ${ }^{144}$ This suggests a possible mechanism for the increased risk associated with possession of the APOE $\varepsilon 4$ allele.

\section{ACUTE PHASE RESPONSE}

The presence of ACT, an acute phase protein, in amyloid plaques ${ }^{9-11}$ and its raised concentrations in the cerebrospinal fluid of patients with Alzheimer's disease ${ }^{145}$ suggest that the acute phase response may be important in Alzheimer's disease. Tumour necrosis factor (TNF), another acute phase protein, has also been reported to be raised in the circulation of patients with Alzheimer's disease. ${ }^{146}$ Furthermore, other acute phase proteins have been detected immunohistochemically in association with senile plaques in the brains of patients with Alzheimer's disease including complement proteins, ${ }^{147}$ interleukin 6 (IL-6), and $\alpha_{2}$ macroglobulin. ${ }^{79}$ Recent evidence suggests that $\alpha_{2}$ macroglobulin might be genetically associated with Alzheimer's disease. $^{84}$

ACT is upregulated in response to inflammation, stimulated by factors such as IL-1, IL-6, TNF, transforming growth factor $\beta 1$ (TGF- $\beta 1),{ }^{148}$ and oncostatin M. ${ }^{149}$ IL- 1 is also able to induce expression of $\beta$ APP in cell culture, ${ }^{150}$ and is known to be increased in the brains of patients with Alzheimer's disease. ${ }^{151}$

It can be hypothesised that the acute phase response is triggered in the Alzheimer's disease brain in response to cell stress (such as injury, age related neuronal damage, and viral infection) resulting in increased concentrations of $\beta A P P$ and ACT. This increased production of $\beta A P P$ might influence metabolism, causing more to be processed to produce amyloidogenic $A \beta_{1-42}$. The increased concentrations of ACT might stimulate aggregation of $A \beta$ fibrils to form amyloid plaques, and this aggregated A $\beta$ could then act as a further cause of cell stress, resulting in stimulation of the acute phase response in a positive feedback loop (fig 4).

OXIDATIVE STRESS

The identification of oxidation markers, including antioxidant enzymes ${ }^{152}$ and heat shock proteins, ${ }^{153}$ in the neuropathological lesions of the disease suggests that oxidative stress is important in the pathogenesis of Alzheimer's disease. Evidence also suggests that the neurotoxicity of $\mathrm{A} \beta$ might be mediated by oxygen 


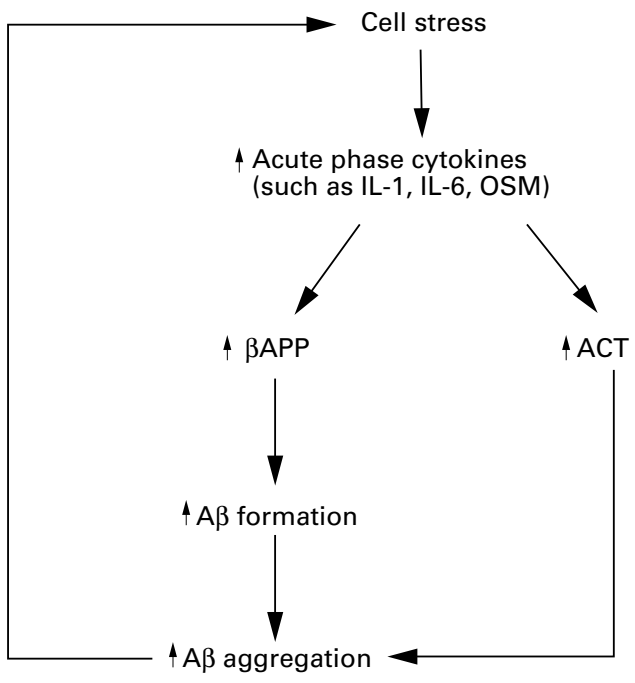

Figure 4 The possible role of the acute phase response in amyloid formation. Cell stress results in production of acute phase cytokines, which upregulate expression of $\beta A P P$ and $A C T$. This results in increased $A \beta$ formation and aggregation, leading to further cell stress and activation of the acute phase response in a positive feedback loop. OSM, oncostatin $M$.

free radicals. ${ }^{154}$ However, there is controversy over whether oxidative stress is a causative factor in Alzheimer's disease or a consequence of A $\beta$ deposition. Studies in cell culture suggest that oxidative stress can shift APP processing in favour of increased $A \beta$ production, ${ }^{155}$ supporting the "stress first" hypothesis. ${ }^{156}$ It has also been demonstrated that PS mutations are able to promote oxidative stress in neurons. ${ }^{157} 158$

OXIDATIVE PHOSPHORYLATION DEFECTS

Oxidative phosphorylation (OXPHOS) generates mitochondrial ATP and is the main source of energy for a number of organs and tissues including brain, muscle, heart, kidney, and liver. The OXPHOS system is known to decline with age, ${ }^{159-161}$ possibly as a result of accumulation of damage to mitochondrial DNA caused by oxygen free radicals, a byproduct of OXPHOS. Evidence suggests that OXPHOS defects may play a role in the pathogenesis of Alzheimer's disease. It has been shown that patients with Alzheimer's disease have OXPHOS defects in a number of tissues. ${ }^{162} 163$ Mitochondrial DNA mutations have been reported to influence the risk of Alzheimer's disease, and could lead to an increased rate of age related decline in the OXPHOS system.

APOPTOSIS

Apoptosis is a form of cell death characterised by condensation of nuclear chromatin, cytoplasmic condensation, DNA fragmentation, and maintenance of membrane integrity. Extensive loss of neurons is characteristic of certain areas of the Alzheimer's disease brain, but the mechanism of this neuronal cell death is unknown. Apoptosis has been implicated in Alzheimer's disease because of the ability of $A \beta$ to induce apoptosis in cultured neurons. ${ }^{164} 165$ Familial Alzheimer's disease mutant APP has also been demonstrated to induce apoptosis in

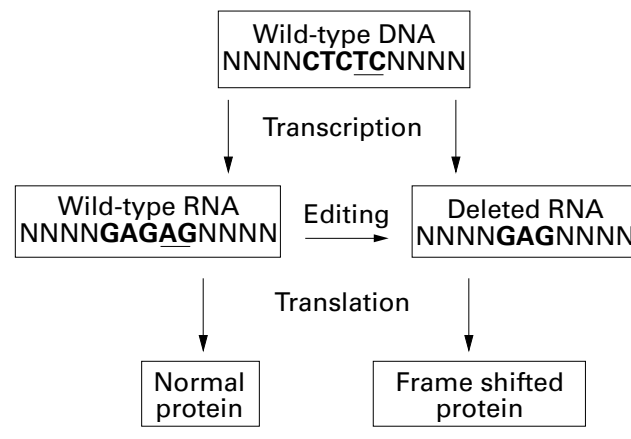

Figure 5 Mechanism by which wild-type DNA can give rise to mutant protein as a result of frameshift mutations in $R N A$. Such mutations have been detected in $\beta A P P$ and Ubi-B in Alzheimer's disease. ${ }^{175}$

vitro, ${ }^{166}$ and mutations in both PS-1 and PS-2 sensitise cells to pro-apoptotic stimuli. ${ }^{157} 158167$ Increased concentrations of the apoptosis promoting protein Bax have been reported in response to $A \beta$ in vitro, ${ }^{168}$ and in Alzheimer's disease neurons in vivo. ${ }^{169}$

However, the proportion of neurons in brains affected by Alzheimer's disease that actually die by apoptosis rather than necrosis is not known. DNA fragmentation has been observed in Alzheimer's disease brain cells $^{170-173}$; however, most of these neurons lack the characteristic morphological features of apoptosis. ${ }^{171} 172$ The assay of apoptosis specific protein, a marker for late stage apoptosis in Alzheimer's disease brains suggests that most dystrophic neurons in affected brains exhibit necrosis rather than apoptosis. ${ }^{173}$

FRAMESHIFT MUTATIONS

Dinucleotide deletions $(\triangle \mathrm{GA})$ within GAGAG motifs of the $\beta A P P$ and ubiquitin $B$ (Ubi-B) genes have been suggested to play a role in both early and late onset sporadic Alzheimer's disease. ${ }^{174}$ Frameshift mutations appear to be introduced during protein synthesis that are not present in genomic DNA. Aberrant forms of $\beta$ APP and Ubi-B proteins were found to be more prominent in Alzheimer's disease brains than in control brains.

The mechanism by which a wild-type gene can give rise to a mutant protein is unclear. It could be via a defect during transcription, or an editing mechanism in the RNA (fig 5). Presumably, aberrant proteins arising from errors during protein synthesis would accumulate with age, possibly explaining the increased risk of Alzheimer's disease with age. However, it is possible that the mutant proteins arise as a result of damage already present in the Alzheimer's disease brain, rather than being a causative factor in the disease.

ADVANCED GLYCATION ENDPRODUCTS

Advanced glycation endproducts are a heterogeneous group of adducts arising via nonenzymatic reactions between reducing sugars and amine groups on proteins. This modification is irreversible, and advanced glycation endproducts accumulate during normal aging. ${ }^{175} 176$ Advanced glycation endproducts have been implicated in the pathogenesis of Alzheimer's disease; diseased brains have been 
reported to contain significantly higher concentrations of advanced glycation endproducts than age matched control brains and advanced glycation endproduct modified $\mathrm{A} \beta$ has been demonstrated to accelerate amyloid aggregation in vitro. ${ }^{177}$ Advanced glycation endproducts colocalise with apoE, and it has been hypothesised that advanced glycation endproduct modified proteins bind to apoE and contribute to the formation of senile plaques. ${ }^{178} \mathrm{~A}$ greater binding affinity for advanced glycation endproducts has been demonstrated with apoE $\varepsilon 4$ compared with apoE $\varepsilon 3$, and this might have pathogenic consequences in vivo. ${ }^{178}$

\section{Summary}

Although new discoveries are being made constantly in this field, the pathogenesis of Alzheimer's disease remains poorly understood. The question remains, what causes Alzheimer's disease and why do some individuals develop the disease while others live into old age with no signs of dementia? Molecular genetic research has shown that there is no simple answer to this question. Alzheimer's disease is a complex polygenic disorder and many of the factors involved have yet to be identified. While the disease process remains largely a mystery, development of effective treatment is obviously difficult. This difficulty is compounded by problems with accurate diagnosis, resulting in heterogeneous groups of patients who may respond differently to treatment. The discovery of further genetic factors involved in the disease could lead not only to development of a better diagnostic profile, but to an increased understanding of the disease process.

We thank Dr K Robson and Professor J Lowe (Division of Pathology, School of Clinical Laboratory Sciences, Queen's Medical Centre, Nottingham) for providing the photographs used in this article. We would also like to thank the Trent Health used in this article. We would also like to thank the Trent Health Research Scheme for financial supp
University for the studentship for L.T.

1 Alzheimer A. Uber Eine Eigenartige Erkrankung der Hirnrinde. Allgemeine Zeitschrift fur Psychiatrie 1907;64:146-8.

2 Rocca WA, Hofman A, Brayne C, et al. Frequency and distribution of Alzheimer's-disease in Europe - a collaborative study of 1980-1990 prevalence findings. Ann Neurol 1991; 30:381-90.

3 Walsh JS, Welch HG, Larson EB. Survival of outpatients with Alzheimer-type dementia. Ann Intern Med 1990;113 429-34.

4 Goedert M. Tau-protein and the neurofibrillary pathology of Alzheimer's-disease. Trends Neurosci 1993;16:460-5.

5 Glenner GG, Wong CW. Alzheimer's-disease-initial report of the purification and characterization of a novel cerebrovascular amyloid protein. Biochem Biophys Res Commun 1984;120:885-90.

6 Jarrett JT, Berger EP, Lansbury PT. The carboxy terminus of the beta-amyloid protein is critical for the seeding of of the beta-amyloid protein is critical for the seeding of amyloid formation-implications for the pathoge

7 Kang J, Lemaire HG, Unterbeck A, et al. The precursor of Alzheimer's-disease amyloid-A4 protein resembles a cellsurface receptor. Nature 1987;325:733-6.

8 Tanzi RE, Gusella JF, Watkins PC, et al. Amyloid beta-protein gene-cDNA, messenger-RNA distribution, and genetic-linkage near the Alzheimer locus. Science 1987 235:880-4.

9 Abraham CR, Selkoe DJ, Potter H. Immunochemical identification of the serine protease inhibitor alpha-1antichymotrypsin in the brain amyloid deposits of Alzheimer's-disease. Cell 1988;52:487-501.

10 Rozemuller JM, Abbink JJ, Kamp AM, et al. Distribution pattern and functional-state of alpha-1-antichymotrypsin in plaques and vascular amyloid in Alzheimer'sin plaques and vascular amyloid in Alzheimer'santibodies against native and inactivated alpha-1antibodies against native and inactivated alpha-1
antichymotrypsin. Acta Neuropathol 1991;82:200-7.
11 Shoji M, Hirai S, Yamaguchi $\mathrm{H}$, et al. Alpha-1antichymotrypsin is present in diffuse senile plaques-a comparative-study of beta-protein and alpha-1ntichymotrypsin immunostaining in the Alzheimer brain. Am 7 Pathol 1991;138:247-57.

12 Namba Y, Tomonaga M, Kawasaki H, et al. Apolipoprotein-E immunoreactivity in cerebral amyloid deposits and neurofibrillary tangles in Alzheimer's-disease and kuru plaque amyloid in Creutzfeldt-Jakob disease. Brain Res 1991;541:163-6.

13 Lee VMY, Balin BJ, Otvos L, et al. A68-a major subunit of paired helical filaments and derivatized forms of normaltau. Science 1991;251:675-8.

14 Morishima-Kawashima M, Hasegawa M, Takio K, et al. Ubiquitin is conjugated with amino-terminally processed tau in paired helical filaments. Neuron 1993;10:1151-60.

15 Raiha I, Kaprio J, Koskenvuo M, et al. Alzheimer's-disease in Finnish twins. Lancet 1996;347:573-8.

16 Nee LE, Eldridge R, Sunderland T, et al. Dementia of the Alzheimer type-clinical and family study of 22 twin pairs. Neurology 1987;37:359-63.

17 VanDuijn CM, Stijnen T, Hofman A. Risk-factors for Alzheimers-disease - overview of the Eurodem collaborative reanalysis of case-control studies. Int F Epidemiol 1991; 20:S4-12.

18 Goate A, Chartierharlin MC, Mullan M, et al. Segregation of a missense mutation in the amyloid precursor protein gene with familial Alzheimer's-disease. Nature 1991;349: 704-6.

19 Chartier-Harlin M-C, Crawford F, Houlden H, et al. Earlyonset Alzheimer's disease caused by mutations at codon 717 of the B-amyloid precursor protein gene. Nature 1991; 353:844-6.

20 Mullan M, Crawford F, Axelman K, et al. A pathogenic mutation for probable Alzheimer's-disease in the APP gene at the N-terminus of beta-amyloid. Nat Genet 1992;1:3457 .

21 Murrell J, Farlow M, Ghetti B, et al. A mutation in the amyloid precursor protein associated with hereditary

22 Hendriks L, Vanduijn CM, Cras P, et al. Presenile-dementia and cerebral-hemorrhage linked to a mutation at codon692 of the beta-amyloid precursor protein gene. Nat Genet 1992;1:218-21.

23 Levy E, Carman MD, Fernandezmadrid IJ, et al. Mutation of the Alzheimer's-disease amyloid gene in hereditary cerebralhemorrhage, Dutch type. Science 1990;248:1124-6.

24 Goate AM. Molecular genetics of Alzheimer's disease. Geriatrics 1997;52:S9-17.

25 Van Broeckhoven C, Backhovens H, Cruts $M$, et al. Mapping of a gene predisposing to early-onset Alzheimer'sdisease to chromosome 14q24.3. Nat Genet 1992;2:335-9.

26 Schellenberg GD, Bird TD, Wijsman EM, et al. Geneticlinkage evidence for a familial Alzheimer's-disease locus on linkage evidence for a familial Alzheimer's-dise
chromosome-14. Science 1992;258:668-71.

27 St George Hyslop P, Haines J, Rogaev E, et al. Geneticevidence for a novel familial Alzheimer's-disease locus on chromosome-14. Nat Genet 1992;2:330-4.

28 Campion D, Brice A, Dumanchin C, et al. A novel presenilin-1 mutation resulting in familial Alzheimer'sdisease with an onset age of 29 years. Neuroreport $1996 ; 7: 1582-4$.

29 Perez-Tur J, Froelich S, Prihar G, et al. A mutation in Alzheimer's-disease destroying a splice acceptor site in the presenilin-1 gene. Neuroreport 1995;7:297-301.

30 Van Broeckhoven C. Presenilins and Alzheimer-disease. Nat Genet 1995;11:230-2.

31 Levitan D, Greenwald I. Facilitation of lin-12-mediated signaling by Sel-12, a Caenorhabditis-elegans S182 Alzheimer's-disease gene. Nature 1995;377:351-4.

32 Wong PC, Zheng $\mathrm{H}$, Chen $\mathrm{H}$, et al. Presenilin 1 is required for Notch1 DII1 expression in the paraxial mesoderm. Nature 1997;387:288-92.

33 Shen J, Bronson RT, Chen DF, et al. Skeletal and CNS defects in presenilin-1-deficient mice. Cell 1997;89:62939.

34 Levy-Lahad E, Wijsman EM, Nemens E, et al. A familial Alzheimer's-disease locus on chromosome-1. Science 1995; 269:970-3.

35 Levy-Lahad E, Wasco W, Poorkaj P, et al. Candidate gene for the chromosome-1 familial Alzheimer's-disease locus. Science 1995;269:973-7.

36 Duff K, Eckman C, Zehr C, et al. Increased amyloid-beta$42(43)$ in brains of mice expressing mutant presenilin-1. Nature 1996;383:710-3.

37 Scheuner D, Eckman C, Jensen M, et al. Secreted amyloid beta-protein similar to that in the senile plaques of Alzheimer's-disease is increased in-vivo by the presenilin-1 and presenilin-2 and APP mutations linked to familial Alzheimer's-disease. Nat Med 1996;2:864-70.

38 Citron M, Westaway D, Xia WM, et al. Mutant presenilins of Alzheimer's disease increase production of 42-residue amyloid beta-protein in both transfected cells and transgenic mice. Nat Med 1997;3:67-72.

39 Lee MK, Borchelt DR, Kim G, et al. Hyperaccumulation of FAD-linked presenilin 1 variants in vivo. Nat Med 1997;3: $756-60$

40 Schellenberg GD, Deeb SS, Boehnke M, et al. Association of an apolipoprotein-CII allele with familial dementia of the Alzheimer type. $\mathcal{F}$ Neurogenet $1987 ; 4: 97-108$.

41 Schellenberg GD, Boehnke M, Wijsman EM, et al. Genetic association and linkage analysis of the apolipoprotein-CII association and linkage analysis of the apolipoprotein-CII
locus and familial Alzheimer's-disease. Ann Neurol 1992; 31:223-7. 
42 Pericak-Vance MA, Bebout JL, Gaskell PC, et al. Linkage studies in familial Alzheimer-disease-evidence for
chromosome-19 linkage. Am F Hum Genet 1991;48:103450 .

43 Corder EH, Saunders AM, Strittmatter WJ, et al. Gene dose of apolipoprotein-E type-4 allele and the risk of Alzheimer's-disease in late-onset families. Science 1993; 261:921-3.

44 Roses AD, Saunders AM, Strittmatter WJ, et al. Association of apolipoprotein-E allele-E4 with late-onset familial and sporadic Alzheimer's-disease. Neurology 1993;43:A192.

45 Saunders AM, Strittmatter WJ, Schmechel D, et al. Association of apolipoprotein-E allele epsilon- 4 with late-onset familial and sporadic Alzheimer's-disease. Neurology 1993; 43:1467-72.

46 Chartier-Harlin MC, Parfitt M, Legrain S, et al. Apolipoprotein-E, epsilon-4 allele as a major risk factor for sporadic early and late-onset forms of Alzheimer'sdisease-analysis of the $19 \mathrm{q} 13.2$ chromosomal region. disease-analysis of the $19 \mathrm{q} 13.2$
Hum Mol Genet 1994;3:569-74.

47 Okuizumi K, Onodera O, Tanaka H, et al. ApoE-epsilon-4 and early-onset Alzheimers. Nat Genet 1994;7:10-1.

48 Poirier J, Davignon J, Bouthillier D, et al. Apolipoprotein-E polymorphism and Alzheimer's-disease. Lancet 1993;342: $697-9$

49 Tsai MS, Tangalos EG, Petersen RC, et al. ApolipoproteinE-risk factor for Alzheimer-disease. Am f Hum Genet 1994;54:643-9.

50 Payami H, Montee KR, Kaye JA, et al. Alzheimer's-disease, apolipoprotein $\mathrm{E} 4$, and gender. $\mathcal{F} A M A$ 1994;271:1316-17.

51 Payami H, Zareparsi S, Montee KR, et al. Gender difference in apolipoprotein E-associated risk for familial Alzheimerdisease-a possible clue to the higher incidence of Alzheimer-disease in women. Am f Hum Genet 1996;58: 803-11.

52 Corder EH, Saunders AM, Strittmatter WJ, et al. The apolipoprotein-E E4 allele and sex-specific risk of Alzheimer's-disease. $7 A M A$ 1995;273:373-4.

53 Bickeboller H, Campion D, Brice A, et al. Apolipoprotein E and Alzheimer disease: genotype-specific risks by age and sex. Am f Hum Genet 1997;60:439-46.

54 Corder EH, Saunders AM, Risch NJ, et al. Protective effect of apolipoprotein-E type-2 allele for late-onset Alzheimerdisease. Nat Genet 1994;7:180-4.

55 Maestre G, Ottman R, Stern Y, et al. Apolipoprotein-E and Alzheimers-disease-ethnic variation in genotypic risks. Ann Neurol 1995;37:254-9.

56 Sorbi S, Nacmias B, Forleo P, et al. ApoE allele frequencies in Italian sporadic and familial Alzheimer's-disease. Neurosci Lett 1994;177:100-2.

57 VanDuijn CM, Deknijff P, Wehnert A, et al. The apolipoprotein-E epsilon-2 allele is associated with an apolipoprotein-E epsilon-2 allele is associated with an increased risk of early-onset Alzheimer's-dis
reduced survival. Ann Neurol 1995;37:605-10.

58 Lambert JC, Pasquier F, Cottel D, et al. A new polymorphism in the APOE promoter associated with risk of developing Alzheimer's disease. Hum Mol Genet 1998;7 533-40.

59 Bullido MJ, Artiga MJ, Recuero M, et al. A polymorphism in the regulatory region of APOE associated with risk for Alzheimer's dementia. Nat Genet 1998;18:69-71.

60 Song YQ, Rogaeva E, Premkumar S, et al. Absence of association between Alzheimer disease and the -491 regulatory region polymorphism of APOE. Neurosci Lett 1998;250:189-92.

61 Itzhaki RF, Lin WR, Shang DH, et al. Herpes simplex virus type 1 in brain and risk of Alzheimer's disease. Lancet type 1 in brain
$1997 ; 349: 241-4$.

62 Sakai J, Hoshino A, Takahashi S, et al. Structure, chromosome location, and expression of the human very-low-density lipoprotein receptor gene. $f \mathrm{Biol}$ Chem 1994;269:2173-82.

63 Takahashi S, Kawarabayasi Y, Nakai T, et al. Rabbit very low-density-lipoprotein receptor-a low-density-lipoprotein receptor-like protein with distinct ligand specificity. Proc Natl Acad Sci USA 1992;89:9252-6.

64 Okuizumi K, Onodera O, Namba Y, et al. Genetic association of the very-low-density lipoprotein (VLDL)

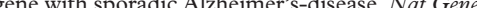
1995;11:207-9.

65 Chung H, Roberts CT, Greenberg S, et al. Lack of association of trinucleotide repeat polymorphisms in the very-low-density lipoprotein receptor gene with very-low-density lipoprotein receptor gene

66 Okuizumi K, Onodera O, Seki K, et al. Lack of association of very-low-density lipoprotein receptor gene polymorphism with Caucasian Alzheimer's-disease. Ann Neurol 1996;40. 251-4.

67 Pritchard ML, Saunders AM, Gaskell PC, et al. No association between very-low-density lipoprotein receptor sians. Neurosci Lett 1996;209:105-8

68 Lendon CL, Talbot CJ, Craddock NJ, et al. Genetic association studies between dementia of the Alzheimer's type and three receptors for apolipoprotein $\mathrm{E}$ in a Caucasian population. Neurosci Lett 1997;222:187-90

69 Fallin D, Gauntlett AC, Scibelli P, et al. No association between the very low density lipoprotein receptor gene and late-onset Alzheimer's disease nor interaction with the apolipoprotein E gene in population-based and clinic samples. Genet Epidemiol 1997;14:299-305.

70 Jokinen E, Sakai J, Yamamoto T, et al. CGG triple repeat polymorphism in VLDL receptor (VLDL-R) gene. Hum Mol Genet 1994;3:521.
71 Arinami T, Takekoshi K, Yanagi H, et al. The 5-repeat allele in the very-low-density lipoprotein receptor gene polymorphism is not increased in sporadic Al

72 Clatworthy AE, GomezIsla T, Rebeck GW, et al. Lack of association of a polymorphism in the low-density lipoproein receptor-related protein gene with Alzheimer disease. Arch Neurol 1997;54:1289-92.

73 Wavrant-DeVrieze F, PerezTur J, Lambert JC, et al. Association between the low density lipoprotein receptor-related protein (LRP) and Alzheimer's disease. Neurosci Lett 1997; 227:68-70.

74 Fallin D, Kundtz A, Town T, et al. No association between the low density lipoprotein receptor-related protein (LRP) gene and late-onset Alzheimer's disease in a communitybased sample. Neurosci Lett 1997;233:145-7.

75 Kang DE, Saitoh T, Chen X, et al. Genetic association of the low-density lipoprotein receptor-related protein gene (LRP), an apolipoprotein E receptor, with late-onset Alzheimer's disease. Neurology 1997;49:56-61.

76 Lambert JC, Wavrant-DeVrieze F, Amouyel P, et al. Association at LRP gene locus with sporadic late-onset Alzheimer's disease. Lancet 1998;351:1787-8.

77 Pericak-Vance MA, Bass MP, Yamaoka LH, et al. Complete genomic screen in late-onset familial Alzheimer disease278:1237-41.

78 Rebeck GW, Harr SD, Strickland DK, et al. Multiple, diverse senile plaque-associated proteins are ligands of an apolipoprotein-E receptor, the alpha(2)-macroglobulin receptor low-density-lipoprotein receptor-related protein. Ann Neurol 1995;37:211-17.

79 Du YS, Ni BH, Glinn M, et al. Alpha(2)-macroglobulin as a beta-amyloid peptide-binding plasma protein. $\mathcal{F}$ Neurochem 997;69:299-305

80 Hughes SR, Khorkova O, Goyal S, et al. Alpha(2)macroglobulin associates with beta-amyloid peptide and prevents fibril formation. Proc Natl Acad Sci USA 1998;95: 3275-80.

81 Du YS, Bales KR, Dodel RC, et al. Alpha(2)-macroglobulin attenuates beta-amyloid peptide 1-40 fibril formation and associated neurotoxicity of cultured fetal rat cortical neurons. F Neurochem 1998;70:1182-8.

82 Kounnas MZ, Moir RD, Rebeck GW, et al. LDL receptor-related protein, a multifunctional ApoE receptor, receptor-related protein, a multifunctional ApoE receptor, ates its degradation. Cell 1995;82:331-40.

83 Matthijs G, Marynen P. A deletion polymorphism in the human alpha-2-macroglobulin (A2M) gene. Nucleic Acids Res 1991;19:5102.

84 Blacker D, Wilcox MA, Laird NM, et al. Alpha-2macroglobulin is genetically associated with Alzheimer disease. Nat Genet 1998;19:357-60.

85 Schellenberg GD, Payami H, Wijsman EM, et al. Chromosome-14 and late-onset familial Alzheimer-disease (FAD). Am f Hum Genet 1993;53:619-28.

86 Wragg $M$, Hutton $M$, Talbot C, et al. Genetic association between intronic polymorphism in presenilin-1 gene and late-onset Alzheimer's-disease. Lancet 1996;347:509-12.

87 Kehoe P, Williams J, Lovestone S, et al. Presenilin-1 polymorphism and Alzheimer's-disease. Lancet 1996;347: 1185 .

88 Higuchi S, Muramatsu T, Matsushita S, et al. Presenilin-1 polymorphism and Alzheimer's-disease. Lancet 1996;347: 1186.

89 Scott WK, Roses AD, Haines JL, et al. Presenilin-1 polymorphism and Alzheimer's-disease. Lancet 1996;347 1560

90 Perez-Tur J, Wavrant-DeVrieze F, Lambert JC, et al. Presenilin-1 polymorphism and Alzheimer's-disease. Lancet 1996;347:1560-1.

91 Tysoe C, Whittaker J, Cairns NJ, et al. Presenilin-1 intron 8 polymorphism is not associated with autopsy-confirmed polymorphism is not associated with autopsy-confirmed 9.

92 Tysoe C, Galinsky D, Robinson D, et al. Analysis of alpha-1 antichymotrypsin, presenilin-1, angiotensin- converting enzyme, and methylenetetrahydrofolate reductase loci as
candidates for dementia. Am 7 Med Genet 1997;74:207-12.

93 Perry EK, Perry RH, Blessed G, et al. Changes in brain cholinesterases in senile dementia of Alzheimer type. Neuropathol Appl Neurobiol 1978;4:273-7.

94 Carson KA, Geula C, Mesulam MM. Electron-microscopic localization of cholinesterase activity in Alzheimer braintissue. Brain Res 1991;540:204-8.

95 Mesulam MM, Geula C. Butyrylcholinesterase reactivity differentiates the amyloid plaques of aging from those of dementia. Ann Neurol 1994;36:722-7.

96 Gomez-Ramos P, Bouras C, Moran MA. Ultrastructurallocalization of butyrylcholinesterase on neurofibrillary degeneration sites in the brains of aged and Alzheimer'sdisease patients. Brain Res 1994;640:17-24.

97 Bartels CF, Jensen FS, Lockridge O, et al. DNA mutation associated with the human butyrylcholinesterase K-variant and its linkage to the atypical variant mutation and other polymorphic sites. Am f Hum Genet 1992;50:1086-103.

98 Lehmann DJ, Johnston C, Smith AD. Synergy between the genes for butyrylcholinesterase K variant and apolipopro-
tein E4 in late-onset confirmed Alzheimer's disease. Hum Mol Genet 1997;6:1933-6.

99 Brindle N, Song Y, Rogaeva E, et al. Analysis of the butyrylcholinesterase gene and nearby chromosome 3 markers in Alzheimer disease. Hum Mol Genet 1998;7:933-5. 
100 Singleton AB, Smith G, Gibson AM, et al. No association between the $\mathrm{K}$ variant of the butyrylcholinesterase gene
and pathologically confirmed Alzheimer's disease. Hum and pathologically confir

$101 \mathrm{Ma} \mathrm{JY}$, Yee A, Brewer HB, et al. Amyloid-associated proteins alpha(1)-antichymotrypsin and apolipoprotein-E promote assembly of Alzheimer beta-protein into filaments. Nature 1994;372:92-4

102 Kamboh MI, Sanghera DK, Ferrell RE, et al. APOE4associated Alzheimer's-disease risk is modified by alpha-1antichymotrypsin polymorphism. Nat Genet 1995;10:4868.

103 Thome J, Baumer A, Kornhuber J, et al. Alpha-1antichymotrypsin bi-allele polymorphism, apolipoprotein-E tri-allele polymorphism and genetic risk of Alzheimer's syndrome. $\mathcal{F}$ Neural Transm Park Dis Dement Sect 1995;10:207-12.

104 Yoshiiwa A, Kamino K, Yamamoto H, et al. Alpha(1)antichymotrypsin as a risk modifier for late-onset antichymotrypsin as a risk modifier for late-onset allele carriers. Ann Neurol 1997;42:115-17.

105 Yamamoto M, Kondo I, Ogawa N, et al. Genetic association between susceptibility to Parkinson's disease and alpha(1)-antichymotrypsin polymorphism. Brain Res 1997;759:153-5.

106 Nacmias B, Tedde A, Latorraca S, et al. Apolipoprotein-E and alpha(1)-antichymotrypsin polymorphism in Alzheimer's-disease. Ann Neurol 1996;40:678-80.

107 Fallin D, Reading S, Schinka J, et al. No interaction between the APOE and the alpha-1-antichymotrypsin genes on risk for

108 Didierjean O, Martinez M, Campion D, et al. No effect of the alpha 1-antichymotrypsin A allele in Alzheimer's disease. F Neurol Neurosurg Psychiatry 1997;63:103-5.

109 Talbot C, Houlden H, Craddock N, et al. Polymorphism in AACT gene may lower age-of-onset of Alzheimer's-disease. Neuroreport 1996:7:534-6.

110 Murphy GM, Sullivan EV, Gallagher Thompson D, et al. No association between the alpha 1-antichymotrypsin A allele and Alzheimer's disease. Neurology 1997;48:1313-16.

111 Haines JL, Pritchard ML, Saunders AM, et al. No association between alpha 1-antichymotrypsin and familia Alzheimer's disease. Ann N Y Acad Sci 1996;802:35-41.

112 Haines JL, Pritchard ML, Saunders AM, et al. No genetic effect of alpha(1)-antichymotrypsin in Alzheimer-disease. Genomics 1996;33:53-6.

113 Morgan K, Morgan L, Carpenter K, et al. Microsatellite polymorphism of the alpha(1)-antichymotrypsin gene locus associated with sporadic Alzheimer's disease. Hum Genet 1997;99:27-31.

114 Edland SD, Silverman JM, Peskind ER, et al. Increased risk of dementia in mothers of Alzheimer's-disease cases-
evidence for maternal inheritance. Neurology 1996;47:2546.

115 Davis RE, Miller S, Herrnstadt C, et al. Mutations in mitochondrial cytochrome $\mathrm{C}$ oxidase genes segregate with lateonset Alzheimer disease. Proc Natl Acad Sci USA 1997;94: 4526-31.

116 Lin FH, Lin R, Wisniewski HM, et al. Detection of point mutations in codon-331 of mitochondrial NADH dehydrogenase subunit-2 in Alzheimer brains. Biochem Biophys Res Commun 1992;182:238-46.

117 Hutchin TP, Heath PR, Pearson RCA, et al. Mitochondrial DNA mutations in Alzheimer's disease. Biochem Biophys Res Commun 1997;241:221-5.

118 Petruzzella V, Chen X, Schon EA. Is a point mutation in the mitochondrial ND2 gene associated with Alzheimer'sthe mitochondrial ND2 gene associated with Alzheimer's-

119 Shoffner JM, Brown MD, Torroni A, et al. MitochondrialDNA variants observed in Alzheimer-disease and Parkinson disease patients. Genomics 1993;17:171-84.

120 Hutchin T, Cortopassi G. A mitochondrial-DNA clone is associated with increased risk for Alzeimer-disease. Proc Natl Acad Sci USA 1995;92:6892-5.

121 Wragg MA, Talbot CJ, Morris JC, et al. No association found between Alzheimer's-disease and a mitochondrial transfer-RNA glutamine gene variant. Neurosci Lett 1995; 201:107-10.

122 Tysoe C, Robinson D, Brayne C, et al. The tRNA(Gln) 4336 mitochondrial DNA variant is not a high penetrance mutation which predisposes to dementia before the age of mutation which predisposes to dement 75 years. $\mathcal{F}$ Med Genet 1996;33:1002-6.

123 Zubenko GS, Stiffler JS, Hughes HB, et al. Initial results of a genome survey for novel Alzheimer's disease risk genes: association with a locus on the X chromosome. Am $7 \mathrm{Med}$ association with a locus

124 Lehmann DJ, Johnston C, Cortina Borja M, et al. Age influences the synergy between butyrylcholinesterase $\mathrm{K}$ variant and apolipoprotein E $\varepsilon 4$ in late-onset Alzheimer's disease. In: Doctor BP, et al., eds. Structure and function of cholinesterases and related proteins. New York: Plenum Publishing Corporation, 1998. [In press.]

125 Bowen DM, Smith CB, White P, et al. Neurotransmitterrelated enzymes and indices of hypoxia in senile dementia and other abiotrophies. Brain 1976;99:459-96.

126 Davies P, Maloney AJF. Selective loss of central cholinergic neurons in Alzheimer's disease. Lancet 1976;ii:1403.

127 Perry EK, Perry RH, Blessed G, et al. Necropsy evidence of central cholinergic deficits in senile dementia. Lancet 1977 ; i: 189

128 Wolozin BL, Pruchnicki A, Dickson DW, et al. A neuronal antigen in the brains of Alzheimer patients. Science 1986;232:648-50.
129 Palmer AM, Procter AW, Stratmann GC, et al. Excitatory amino acid-releasing and cholinergic neurons in amino acid-releasing and cholinergic neuron

130 Kish SJ, Elawar M, Schut L, et al. Cognitive deficits in olivopontocerebellar atrophy -implications for the cholinergic hypothesis of Alzheimer's dementia. Ann Neurol $1988 ; 24: 200-6$

131 Hardy JA, Higgins GA. Alzheimer's-disease-the amyloid cascade hypothesis. Science 1992;256:184-5.

132 Whitson JS, Selkoe DJ, Cotman CW. Amyloid-beta protein enhances the survival of hippocampal-neurons in vitro. Science 1989;243:1488-90.

133 Whitson JS, Glabe CG, Shintani E, et al. Beta-amyloid protein promotes neuritic branching in hippocampal protein promotes neuritic branching

134 Yankner BA, Dawes LR, Fisher S, et al. Neurotoxicity of a fragment of the amyloid precursor associated with Alzheimer's-disease. Science 1989;245:417-20.

135 Yankner BA, Duffy LK, Kirschner DA. Neurotrophic and neurotoxic effects of amyloid beta-protein-reversal by tachykinin neuropeptides. Science 1990;250:279-82.

136 Pike CJ, Walencewicz AJ, Glabe CG, et al. In vitro aging of beta-amyloid protein causes peptide aggregation and neurotoxicity. Brain Res 1991;563:311-14.

137 Whitson JS, Mims MP, Strittmatter WJ, et al. Attenuation of the neurotoxic effect of a-beta amyloid peptide by apolipoprotein-E. Biochem Biophys Res Commun 1994;199. 163-70.

138 Aksenov MY, Aksenova MV, Carney JM, et al. Alpha-1antichymotrypsin interaction with a-beta $(1-42)$ does not inhibit fibril formation but attenuates the peptide toxicity. Neurosci Lett 1996;217:117-20.

139 Koh JY, Yang LL, Cotman CW. Beta-amyloid protein increases the vulnerability of cultured cortical-neurons to excitotoxic damage. Brain Res 1990;533:315-20.

140 Baudier J, Cole RD. Phosphorylation of tau-proteins to a state like that in Alzheimer's brain is catalyzed by a calcium calmodulin-dependent kinase and modulated by phospholipids. F Biol Chem 1987;262:17577-83.

141 Braak H, Braak E, Bohl J, et al. Age, neurofibrillary changes, a-beta-amyloid and the onset of Alzheimer'sdisease. Neurosci Lett 1996;210:87-90.

142 Drechsel DN, Hyman AA, Cobb MH, et al. Modulation of the dynamic instability of tubulin assembly by the microtubule-associated protein tau. Mol Biol Cell 1992;3: $1141-54$.

143 Terry RD. The pathogenesis of Alzheimer-disease-an alternative to the amyloid hypothesis. $\mathcal{F}$ Neuropathol Exp Neurol 1996;55:1023-5.

144 Matsubara E, Amari M, Shoji M, et al. CSF alpha-1antichymotrypsin level is elevated in patients with Alzheimer-type dementia. Neurobiol Aging 1990;11:333.

145 Fillit H, Ding W, Buee L, et al. Elevated circulating tumornecrosis-factor levels

146 Eikelenboom P, Hack CE, Kamphorst W, et al. Distribution pattern and functional-state of complement proteins and alpha-1-antichymotrypsin in cerebral beta/A4 deposits in Alzheimer's-disease. Res Immunol 1992;143:617-20.

147 Mackiewicz A, Speroff T, Ganapathi MK, et al. Effects of cytokine combinations on acute phase protein production in two human hepatoma cell lines. F Immunol 1991;146: $3032-7$

148 Kordula T, Rydel RE, Brigham EF, et al. Oncostatin $M$ and the interleukin- 6 and soluble interleukin- 6 receptor complex regulate alpha(1)-antichymotrypsin expression in human cortical astrocytes. F Biol Chem 1998;273:4112-18.

149 Goldgaber D, Harris HW, Hla T, et al. Interleukin-1 regumessenger-RNA in human-endothelial cells. Proc Natl Acad Sci USA 1989;86:7606-10.

150 Griffin WST, Stanley LC, Ling C, et al. Brain interleukin-1 and $S-100$ immunoreactivity are elevated in Down syndrome and Alzheimer-disease. Proc Natl Acad Sci USA syndrome and Alzhe

151 Pappolla MA, Omar RA, Kim KS, et al. Immunohistochemical evidence of antioxidant stress in Alzheimer'sdisease. Am f Pathol 1992;140:621-8.

152 Smith MA, Kutty RK, Richey PL, et al. Heme oxygenase-1 is associated with the neurofibrillary pathology of Alzheimer's-disease. Am $\mathcal{F}$ Pathol 1994;145:42-7.

153 Behl C, Davis JB, Lesley R, et al. Hydrogen-peroxide mediates amyloid-beta protein toxicity. Cell 1994;77:817-

154 Gabuzda D, Busciglio J, Chen LB, et al. Inhibition of energy-metabolism alters the processing of amyloid precursor protein and induces a potentially amyloidogenic derivative. F Biol Chem 1994;269:13623-8.

155 Mattson MP, Guo Q, Furukawa K, et al. Presenilins, the endoplasmic reticulum, and neuronal apoptosis in Alzheimer's disease. F Neurochem 1998;70:1-14.

56 Guo Q, Furukawa K, Sopher BL, et al. Alzheimer's PSmutation perturbs calcium homeostasis and sensitizes PC12 cells to death induced by amyloid beta-peptide. Neuroreport 1996;8:379-83.

157 Guo Q, Sopher BL, Furukawa K, et al. Alzheimer's presenilin mutation sensitizes neural cells to apoptosis induced by trophic factor withdrawal and amyloid beta-peptide: involvement of calcium and oxyradicals. 7 Neurosci 1997; 17:4212-22.

158 Trounce I, Byrne E, Marzuki S. Decline in skeletal-muscle mitochondrial respiratory-chain function-possible factor in aging. Lancet 1989;1:637-9. 
159 Mullerhocker J. Cytochrome-C-oxidase deficient cardiomyocytes in the human heart-an age-related
phenomenon-a histochemical ultracytochemical study. Am f Pathol 1989;134:1167-73.

160 Yen TC, Chen YS, King KL, et al. Liver mitochondrial respiratory functions decline with age. Biochem Biophys Res Commun 1989;165:994-1003.

161 Sims NR, Finegan JM, Blass JP. Altered metabolic properties of cultured skin fibroblasts in Alzheimer's-disease. Ann Neurol 1987;21:451-7.

162 Parker WD, Filley CM, Parks JK. Cytochrome-oxidase deficiency in Alzheimer's-disease. Neurology 1990;40:1302-3.

163 Forloni G, Chiesa R, Smiroldo S, et al. Apoptosis mediated neurotoxicity induced by chronic application of betaamyloid fragment 25-35. Neuroreport 1993;4:523-6.

164 Loo DT, Copani A, Pike CJ, et al. Apoptosis is induced by beta-amyloid in cultured central-nervous-system neurons. Proc Natl Acad Sci USA 1993;90:7951-5.

165 Yamatsuji T, Okamoto T, Takeda S, et al. Expression of V642 APP mutant causes cellular apoptosis as Alzheimer trait-linked phenotype. EMBO f 1996;15:498-509.

166 Wolozin B, Iwasaki K, Vito P, et al. Participation of presenilin-2 in apoptosis-enhanced basal activity conferred by an Alzheimer mutation. Science 1996;274:1710-13.

167 Paradis E, Douillard H, Koutroumanis M, et al. Amyloid beta peptide of Alzheimer's disease downregulates bcl-2 and upregulates bax expression in human neurons. $f \mathrm{Neu}-$ rosci 1996;16:7533-9.

$168 \mathrm{Su} \mathrm{JH}$, Deng GM, Cotman CW. Bax protein expression is increased in Alzheimer's brain: correlations with DNA damage, Bcl-2 expression, and brain pathology. $7 \mathrm{Neu}$ ropathol Exp Neurol 1997;56:86-93.

169 Dragunow M, Faull RLM, Lawlor P, et al. In-situ evidence for DNA fragmentation in Huntington's-disease striatum and Alzheimer's-disease temporal lobes. Neuroreport 1995; 6:1053-7.
170 Lassmann $\mathrm{H}$, Bancher C, Breitschopf $\mathrm{H}$, et al. Cell-death in Alzheimer's-disease evaluated by DNA fragmentation in-situ. Acta Neuropathol 1995;89:35-41.

171 Lucassen PJ, Chung WCJ, Kamphorst W, et al. DNA damage distribution in the human brain as shown by in situ end abeling; area-specific differences in aging and Alzheimer disease in the absence of apoptotic morphology. $f$ Neuropathol Exp Neurol 1997;56:887-900.

172 Smale G, Nichols NR, Brady DR, et al. Evidence for apoptotic cell-death in Alzheimer's-disease. Exp Neurol 1995; 133:225-30.

173 Stadelmann C, Bruck W, Bancher C, et al. Alzheimer disease: DNA fragmentation indicates increased neuronal vulnerability, but not apoptosis. I Neuropathol Exp Neurol 1998;57:456-64.

174 Van Leeuwen FW, deKleijn DPV, vandenHurk HH, et al. Frameshift mutants of beta amyloid precursor protein and ubiquitin-B in Alzheimer's and Down patients. Science 1998;279:242-7.

175 Vlassara H. Recent progress on the biologic and clinicalsignificance of advanced glycosylation end-products. $\mathcal{F} \mathrm{Lab}$ Clin Med 1994;124:19-30.

$176 \mathrm{Li}$ YM, Steffes M, Donnelly T, et al. Prevention of cardiovascular and renal pathology of aging by the advanced glycation inhibitor aminoguanidine. Proc Natl Acad Sci USA 1996;93:3902-7.

177 Vitek MP, Bhattacharya K, Glendening JM, et al. Advanced glycation end-products contribute to amyloidosis in Alzheimer-disease. Proc Natl Acad Sci USA 1994;91: 4766-70.

$178 \mathrm{Li}$ YM, Dickson DW. Enhanced binding of advanced glycation endproducts (AGE) by the ApoE4 isoform links the mechanism of plaque deposition in Alzheimer's disease. Neurosci Lett 1997;226:155-8. 